\title{
INTERROGATING URBAN SPACES: KALI AND THE INTELLECTUAL IN TWO CONTEMPORARY NOVELS
}

\author{
ADRIANA RADUCANU \\ Yeditepe University, Istanbul, Turkey \\ 26 Agustos Yerlesimi, Kayisdagi Cad. \\ 34755, Atasehir/ Istanbul, Turkey \\ adiarna@hotmail.com
}

\begin{abstract}
This article focuses on the complexity of the encounter between two Western male writers and the East as represented by the metropolis of Calcutta and Kali, its patron goddess. The novels under discussion are Dan Simmons' Song of Kali and Paul Theroux's A Dead Hand: A Crime in Calcutta. The theoretical framework of the comparative analysis argues for the conceptual blurring of boundaries between 'flâneur' and 'badaud', elusive hypostases of the male writer protagonists in the Eastern urban context.
\end{abstract}

Keywords: badaud, Calcutta, flâneur, Kali, urban, writer

\section{Introduction}

Some places are too evil to be allowed to exist. Some cities are too wicked to be suffered. Calcutta is such a place [...] Before Calcutta I did not believe in evil certainly not as a force separate from the actions of men [...] Now I dream of nuclear mushroom clouds rising above a city. I see buildings melting into lakes of glass. I see paved streets flowing like rivers of lava and real rivers boiling away in 
great gouts of steam. I see human figures dancing like burning insects, like obscene praying mantises sputtering and bursting against a fiery red background of total destruction. The city is Calcutta. The dreams are not unpleasant. Some places are too evil to be allowed to exist (Simmons 1985: 1)

I have quoted the above paragraph in full, since these opening lines of Dan Simmons' Song of Kali are arguably the most appropriate introduction to a study which draws its substance from the examination of the male gaze and its retrospective appraisal of the destructive encounter between West and East, in the urban context. In the two novels that this paper focuses on, the Western (American) writer and the Eastern city of Calcutta are mutually exclusive. Such is the force of this particular set of binary oppositions that to attempt to comprehend one, to aim to decipher the mystery of man or of city as man's creation, requires the ruthless act of 'killing' the other. Furthermore, the historical, geographical, cultural, and social 'hubbub' which defines the contours of the man versus city dichotomy is, as my paper will reveal, actually genderised into the primordial man versus female, since Kali is comfortably ensconced at the heart of Calcutta, as its patron goddess and thus, as its very symbol.

This study aims to reveal the complexity of the encounter between two Western male writers and the East as represented by the metropolis of Calcutta and Kali, its patron deity. The novels discussed are Dan Simmons' Song of Kali and Paul Theroux's A Dead Hand: A Crime in Calcutta. The theoretical frame of the comparative analysis argues for the conceptual blurring of boundaries between 'flâneur' and 'badaud', elusive hypostases of the male protagonist, trapped in the Eastern urban context. Apart from its Introduction and Conclusion, the paper contains two main sections: the first part will offer a detailed survey of the negative representations of the 
goddess Kali in Hindu and Western literature and film, while the second will discuss Simmons' and Theroux's novels in the context of the Western concepts of the 'flâneur' and the 'badaud' and their subsequent novelistic adaptation to the requirements of Calcutta, the powerful Eastern setting.

\section{Kali, the fearsome goddess in the East and in the West}

Kali is the Indian subcontinent goddess who has most "captured the imagination of the West"; even today, six-year old children in the Western world know that "she is the evil demoness who the badly-animated hero has to conquer" (Magee:1). The contemporary Western representations of "the black goddess' as a demonic force that needs to be contained (even if not tamed) stem from lingering historical appraisals, in spite of the many attempts made to rescue her from the debris of the colonial imaginarium. Kali is arguably the Tantric deity who provided a strong incentive for the civilising mission carried out by the British in the Indian subcontinent. However biased and deeply flawed by Orientalist undertones this perspective may sound in its implications (the savage Hindus, tainted by their bloody idol, needed to learn the values of mercy, compassion and true piety embodied by Christianity), it is important to remember that Kali's negative image has also been actively nourished by numerous indigenous texts. In literature and film, the British and, as we shall see later on in this chapter, the Americans, exacerbated these negative descriptions, possibly with the aim of further justifying the colonising (cultural, economic and social) project. The following section of this present paper will include a brief survey of Kali's most important textual appearances in Hindu texts. Since this part will help contextualise my argument for the second section, where the emphasis is placed on Kali as the catalyst for the destructive, catastrophic effects of the encounter between West and East, I will focus on 
the literature and films (Eastern and Western) which render her as fearsome, lethal and annihilating.

Kali first emerges as a warrior goddess around the fifth century B.C. in an episode of Mahabharata. There she (and not, as may appear at first sight, Asvatthaman) is supposed to be the true artisan of the assault against the Pandava brothers. She is presented as: "Kali of bloody mouth and eyes, smeared with blood and adorned with garlands, her garment reddened, -holding noose in hand -- binding men and horses and elephants with her terrible snares of death" (Mahabharata 10.8.64-65). She reappears in the Hindu tradition around A.D. 600, as the incarnation of the goddess Durga's fury (in Devi-Mahatmya) (Kripal and McDemott:4). In one episode, the gods, led by Indra, are scared away by Mahisashura, the buffalo demon; in despair, they take refuge with Brahma, Vishnu and Shiva. A solution is found and Kali - as the manifestation of Durga's fury - is born out of the energy emanating from all the assembled gods. Adorned with their many weapons and emblems, she swiftly rushes into battle and decapitates her strong opponent (Menon and Shweder: 90-1). Another episode presents us with the goddess Durga on the point of being attacked by the demons Chanda and Munda. Durga's face blackens with fury and the goddess Kali, like the Greek Athene, who sprang from her father Zeus's head fully armed, is born from Durga's head and with a single blow beheads her opponents (Kinsley:25). In yet another episode Kali is invoked by Durga to help her overcome the demon Raktabija. It is a long and apparently futile fight, because Raktabija has the uncanny ability to replicate himself as he bleeds. To overcome him, Kali resorts to sucking the blood from his body and devouring the many replicas (Kinsley:25). 
Parvati, the celestial consort of Shiva, is another deity that Kali has been traditionally associated with. In Linga-purana, Shiva demands that his wife kill the demon Daruka. Parvati, metamorphosed as Kali from the poison in Shiva's throat, obeys, and defeats Daruka and his companions. Nevertheless, as she has had to be naked and display her genitals in order to achieve this victory (according to a contemporary Oriya story - a rewriting of the Tantric Candi Purana text), her humiliation becomes all-destroying anger (Menon and Shewer:90-1). Only Shiva manages to calm her, by laying himself at her feet. A tamed Kali now "bites her tongue and holds in her anger" (Menon and Shewer:95).

Apart from this splendid, albeit terrible, aspects of Kali as the defeater of various demons, where she acts as the punishing hand of other gods, notable too is her constant presence at the very margins of the Hindu social order (Kinsley:24). In Agni- and Garuda-puranas we encounter a "gaunt" deity of an "awful appearance", who "has fangs, laughs loudly, dances madly, wears a garland of corpses, sits on the back of a ghost, and lives in the cremation ground", and who is generally invoked for "success in wars and against one's enemies" (Kinsley:24). Kali also plays a most interesting role in Bhagavata-purana as the patron deity of a band of thieves whose leader desires to have a son. The outlaws imprison a righteous young Brahmin in the belief that sacrificing him to Kali will achieve the leader's wish. However, the Brahmin's saintliness burns the goddess' statue so that she turns against the thieves, decapitates them in a murderous frenzy, and then starts to play with their heads (Kinsley:24).

Female negative representations of aggression and unleashed fury do not necessarily require Kali's literal presence. Kadambari, a seventh-century drama written by Banabhatta, presents us with Candi (an epithet used for 
Durga and Kali), Malatimadhava, a play by Bhababhuti (early eighth century) introduces Camunda, and Yasatilaka, by Somadeva (eleventh to twelfth century), features Candamari. Candi, Camunda and Candamari are actually avatars of Kali who possess her terrible qualities. Thus, Candi relishes in her devotees' blood offerings, Camunda of the cremation ground, "surrounded by goblins" and "covered with snakes", inspires a female devotee to sacrifice innocent Malati, while Candamari adorns herself with the limbs of corpses, drinks from human skulls, "bathes in rivers of wine or blood, sports in cremation grounds". In addition, Candamari's worshippers practise and enjoy self-torture (Kinsley:24).

Closer to our times, Kali's magnificent, albeit terrible image as an undefeatable deity faded in the era of the reformist Neo-Hindu schools. As Humes states: "Kali worship practices were a superstitious accretion not enjoined in the higher scriptures" (Humes:149). Ram Mohan Roy (17721833), the Bengali artisan of modern India, claimed that the vast majority of the "social ills" of Hinduism could be attributed to certain devotional practices erroneously raised to a religious status by unscrupulous individuals in search of power and wealth (Humes:149). Such practices included the worship of Kali; Ram Mohan Roy found animal sacrifice so repellant that he refused to participate in his own family's customary Kali worship. According to Humes, Ram Mohan Roy's views were of a highly functional nature: as it appeared to him that Kali worship did not facilitate the enhancement of the quality of human life, he relentlessly downplayed the goddess' significance in the interests of the safeguarding of genuine Indian values and spirituality (Humes:149).

The Nobel Prize-winning Rabindranath Tagore, passionate as he was about Bengali poetic traditions, wrote his own version of Kali songs in a 
mixture of Indian and Western genres that includes dialogue, music and dance. He also authored Sacrifice, a play in which he interrogates the gory nature of Kali, the deity who never seems to be able to get her fill of animal sacrifice. At the end of the play, even Kali's priest, who has lost Jaising, his young protégée, to Kali's thirst for blood - Jaising took his own life in order to appease the goddess, who had demanded he kill the king who opposed her - denounces the goddess, calling her "the silly stone, - deaf, dumb, blind, - the whole sorrowing world weeping at her door" (Tagore).

In the West, the organised attempt to demonise Kali was initiated by William Sleeman, the architect of the British Campaign against Thuggees. Sleeman was Head of the Thuggee and Dacoity Department in India from 1835 onwards. These Thuggees, according to him, were Kali-worshippers, a bloodthirsty cult of stranglers and robbers who in the course of a few hundred years were responsible for over a million murders. Kali was their inspiration, through a "unique, omnipotent and undifferentiated principle that is, everything in everything, in good as well as evil" which "set forth the Goddess and ordered her to feed on blood" (Van Woerkens:171).

In Western fiction, Philip Meadows Taylor's Confessions of a Thug (1839), a Victorian best-seller, was the first novel centred on Kali and the Thuggees. However, the protagonist Ameer Ali's relationship with the goddess is of a different nature than that of Sleeman's thugs, in that he is discourteous and cynical regarding Kali's omens: "You are always prating about these foolish omens, as if success lay more in them, than in stout hearts" (Taylor:207). In John Masters' The Deceivers, yet another novel in which Kali features as powerful background, William Savage, an official of the East India Company, disguises himself as a Thug in order to expose their plot, but loses himself in the process. Savage is so captivated by the 
fury of slaughter, the rituals and the whole Kali imagery - in which experiencing unleashed sexuality occupies a central role - that he suffers a highly dangerous split in his consciousness, veering between his own Christian religion and the seductive, exotic allure of the pagan deity.

The first Hollywood film to present Kali and her Thug followers was George Stevens's Gunga Din (1939), based on Rudyard Kipling's eponymous poem. It was shortly followed by the 1959 adventure/horror The Stranglers of Bombay (loosely based on Gunga Din), directed by Terence Fisher. This second feature film horrified its audiences with a grotesque and horrific Kali who impassibly condones dismemberings and ghastly executions. The 1965 Beatles film Help is a manic adventure comedy which opens with an unsuccessful human sacrifice to the Hindu deity Kaili (Kali) and ends on the same note, this time with another possible victim after the initial one is rescued (Hann:4). Steven Spielberg's Indiana Jones and the Temple of Doom (1984), generally considered "a textbook case of Orientalism in film" (Hann:8), is arguably the most famous/infamous feature film focused on Kali and her worshippers. Significantly, this is a collage in terms of imagery, since neither the contemporary Thugs nor the image of the goddess bear any resemblance to the historical ones. Kali manages to keep her name and her grotesque collar of human heads, but an assortment of other essentials are added to the gigantic statue, crowned with a papal headdress, which makes her more like a representation of Christian demonology than a Hindu deity (Van Woerkens: 284). Kali's High Priest sets out to "massacre the British Imperialists, crush the Muslims, and then cause the god of the Christians to crumble into dust". Overall, in Spielberg's film, the blatant Orientalist characteristics give us a Kali bursting with anger and murderous wrath, determined to make the world into her territory. 
As seen from the above survey of Kali-based literature and films, the Western representations of the goddess are, to a large extent, counterparts of the Hindu ones. Nevertheless, one may observe in Western books and films based on Kali a peculiar emphasis on the deity's destructive and worldthreatening qualities, a powerful Orientalist mark which, as the second part of this study will demonstrate, has survived to the present day.

\section{Kali and the Writer in Song of Kali and A Dead Hand: A Crime in Calcutta}

Before the actual analysis of the two selected novels, I would like to introduce the concepts of "flâneur" and "badaud", as they delineate the theoretical chart that marks the urban experience of the protagonists. In the two novels that I am focusing on, the perception of the East (as urban space) by the West (as the human and male interrogator) is the result, I argue, not of "flânerie", but of the writer turned "badaud". This metamorphosis and blurring of boundaries is aided by the powerfully sexualised image of Kali, the Tantric goddess, rendered either through instances of notional ekphrasis, such as dreams, or through mortal 'incarnations', the likes of Kamakhya Bharati in Song of Kali and Mrs Unger in A Dead Hand: A Crime in Calcutta.

The "flâneur" is the urban figure par excellence, invented in the $19^{\text {th }}$ century in Charles Baudelaire's The Painter of Modern Life (1859-1860). There, the French poet depicts the newspaper illustrator Constantin Guys as the stroller figure who "moved through the crowd like a fish through water" (Shaya:48), whose "passion was to become one with the crowd" (Baudelaire 1986:9). In The Crowds (first published in 1861), the prose poem from Paris Spleen, the flâneur is the "poet who enjoys the incomparable privilege 
of being, as he pleases, himself and others", who in the crowd becomes part of "this universal communion", "this ineffable orgy", "this holy prostitution" with delights "more vast and more refined" than "the happy of the world" would ever experience (Baudelaire, quoted in Shaya:48). Although The Crowds describes the flâneur as an ever-victorious hero, Baudelaire's poetry portrays him altogether differently. In The Seven Old Men (1859) the poet flâneur wanders in "the sad street", "steeling my nerves to play a hero's part, in an "ant-seething city, city full of dreams,/Where ghosts by daylight tug the passer's sleeve" (Baudelaire, quoted in Shaya:48). In To a Passerby (1860), the flâneur deciphers "intoxicating sweetness and murderous pleasure" in the eyes of a passing woman of "fugitive beauty" (Baudelaire, quoted in Shaya:49). The "second coming" of the flâneur occurs with his rediscovery by Walter Benjamin in the orbit of Surrealist practices in the 1920s, followed by a third appearance - again through Benjamin - with his Der Flaneur, the central section of his essay on Charles Baudelaire (McDonough:102). Benjamin's text begins with comments on the "physiologies", a formerly popular Parisian genre, in decline in the 1840s, which focused on "the typologies of urban flora" (McDonnough:104) as ideally suitable objects of inquiry for "the flâneur who goes on botanizing on the asphalt" (Benjamin:36). For Benjamin, these urban types "were all harmless and perfect bonhomie" (Benjamin:37), their transparency enabling the flâneur to act as a "connoisseur of human nature, confident of his capacity to rank and judge the strangers along the boulevards" (Mc Donnough:104). Hence, the flâneur could feel quite sure of his ability to categorise and evaluate the passers-by along the boulevards, and could be relieved to recognise that these strangers wished him no harm, that he was free of their malicious intentions (McDonnough:104). Yet, as 
Benjamin states later on, strangers in the crowd do not lend themselves as freely to acts of identification as the flâneur of the "physiologies" might have assumed. On the contrary, the crowd evades shallow categorisations, since "every person, the best as well as the most wretched, carries around a secret which would make him hateful to others if it became known" (Benjamin:38). To survive the game of identifications which can turn sour at any moment, the flâneur has to turn detective in the mystery novel, a new kind of literature that Benjamin proposes. Only this new type of hero can hope to find his way through what is now perceived as the urban jungle and ensure the survival of the transparency formerly provided by the genre of the "physiologies", albeit in a different manner; now it is the result of his "criminological sagacity", a substitute for the imperturbability typical of the flâneur (McDonnough:105).

Quite the opposite of the concept of the "flâneur" is that of the "badaud", another emblematic figure of the individual in the street. The "Grand dictionnaire universel" (1867) defines him as follows: "The badaud is curious; he is astonished by everything he sees, and he shows his contentment of his surprise, by his open, gaping mouth" (quoted in Shaya:49). The "badaud", unlike the flâneur, who is relatively in charge of his surroundings, sampling the metropolitan space at his own pace and, as previously mentioned, generally able to read behind the urban mask of fellow-citizens, is "the curious observer, the rubberneck, the gawker" (Shaya:46):

The flâneur, then, is the man in the crowd, but not of the crowd [...] The flâneur was the gourmet of the street; the badaud was the gourmand. The flâneur observed the city with intelligence and distinction; he turned his overdeveloped sensibilities 
to dwell on mysteries and telling details. The badaud gawked; she sought out a story that would touch her (Shaya:49-50)

In the words of Benjamin, who also contrasted these two highly significant urban types: "In the flâneur, the joy of watching is triumphant. It can concentrate on observation: the result is the amateur detective. Or it can stagnate in the gaper; then the flâneur has turned into the badaud" (Benjamin:62). Arguably, it is Victor Fournel's words in Ce qu'on voit dans les rues de Paris (1867) that most aptly distinguished between the flâneur and the badaud:

The simple flâneur is always in full possession of his individuality. By contrast, the individuality of the badaud disappears, absorbed by the outside world, which ravishes him, which moves him to drunkenness and ecstasy. Under the influence of the spectacle that presents itself to him, the badaud becomes an impersonal creature: he is no longer a man, he is the public, he is the crowd (quoted in Benjamin:69).

After describing the main differences between the concepts of flâneur and badaud, I will now move on to analyse the two novels under discussion in order to gain a perspective on the current meanings of these terms in Simmons' and Theroux's works.

In 1986, Dan Simmons' 1985 Song of Kali won the World Fantasy Award. The plot of this blood-curdling page-turner has at its centre an American writer who travels to Calcutta, where he and his family become victims of the horrific machinations of a Kali-worshipping cult. The novel is arguably a modern Thuggee story, in the vein of Philip Meadows Taylor's Confessions of a Thug and John Masters' The Deceivers. Thus, the American intellectual, although increasingly horrified and infantilised by the 
visceral, life-annihilating nature of Calcutta (whose patron deity is Kali), and having only just managed to survive this unspeakable urban test, is also absorbed, lured and bewitched by the exoticism of the Eastern locale.

Robert Luczack, a not-particularly-successful "assistant editor, poetry editor and unpaid proofreader", albeit "with a newly issued book of poetry to my credit" (Simmons:4), sets out on his intercontinental exploration as a species of literary detective. Thus, he is sent by the magazine he works for to trace a poem believed to be the most recent work of M. Das, a mysterious poet who has been thought dead for the last eight years. What seems to qualify Luzcak for such an undertaking is his having written a piece on some Bengali poetry by Rabindranath Tagore. In addition, he has an Indian wife, Amrita, who "spoke Hindi, Marathi, Tamil, and a little Punjabi as well as German, Russian, and English, but not Bengali" (Simmons:5). Since Bengali is the language of Calcutta, this particular linguistic insufficiency constitutes a 'detail' that raises the curtain on a novelistic universe of amateurish attempts, misunderstandings, misconceptions and approximations culminating in horrible death and loss.

The plot of Paul Theroux's A Dead Hand: A Crime in Calcutta (2010) is initiated by a letter from Mrs Unger, an American philanthropist, asking Jerry Delfont, an American writer who is suffering from writer's block, to solve the mystery of a dead boy found in the hotel room of an Indian friend of her son's. Since he has been experiencing an emotional, professional and financial 'drought', this unusual request, coming as it does from a sensuous and glamorous woman, motivates Delfont to accept the challenge to turn detective, especially since it appears to provide him with a story and a way to overcome Calcutta, the city which "had started to creep on my skin" (Theroux:3). "The day of the letter" actually provides 
protagonist and readers alike with "strange portents", such as a wasp which refuses to leave the hotel room, "the sight of a paralytic child [...] creeping on hands and knees like a wounded animal", and the revelation of his "dancer friend, the willowy Parvati" as an "adept in a kind of Indian martial art" which enables her both to "break your arm" but also to "set it, because if one knows how to injure one must also know how to heal" (Theroux:4-5). Most importantly, this is also the day on which Delfont learns stories about "children disappearing from the streets, kidnapped to work in brothels or workshops, or sold to strangers" (Theroux:5), the portent of all portents, since this is the social puzzle that he will be asked to solve. As the novel progresses, we are exposed to a dark world, an intricate web of philanthropy, sexual obsession and exploitation, where the most atrocious acts of violence and aggression are carried out against children, the tragic epitome of society's most dispossessed.

As has been made clear in the above synopses, the two male protagonists initiate their journeys into Calcutta's urban jungle from the position of flâneurs as investigators, self-styled detectives of sorts, individuals who attempt to claim the setting, the surroundings and the characters and conveniently turn them into personal assets. Robert Luczack, apparently happy paterfamilias, is in fact a writer who desperately desires professional success as a means to make up for what he perceives as (but doesn't confess as) personal inadequacies. The other male protagonist, Jerry Delfont, the author with a "dead hand", accepts the mission offered to him by the mysterious Mrs Unger in the hope that it may provide him with a story which will compensate for the inability of the "travelling writer" (and not the "travel writer") both to settle down and to produce an ever-elusive book. Aware that what he presents to the world is himself as "one of those 
calculated enigmas, self-invented, pretending to be spiritual but ruthlessly worldly, full of bonhomie and travel advice" (Theroux:4), Delfont welcomes the challenge of the flâneur as detective, the deciphering of a true mystery which will bestow meaning on an otherwise unfulfilled life.

However, in both novels the man/intellectual/writer/flâneur is presently disarmed by the sudden and disturbing intervention of the female element which, in a city like Calcutta, depicted in both novels from a Western male perspective, actually signifies the "Kali female". In Simmons" novel, the real-life substitute for Kali is Kamakhya Bharati, whose extreme beauty and powerful sexual aura, from the very beginning, makes Robert Luczack "blink stupidly and look at Amrita", while the "afterimage" of her "stayed in my retinas like a flashbulb's optical echo"; the "sense of voluptuousness" that she exudes "dried the saliva in my mouth and emptied my mind" (Simmons:32). This charming woman who claims to be the poet Das' niece, eager to obtain news about his health from Robert Luczack, represents the very apogee of danger as the attribute of the archetypal villainous female. Not only is she depicted as a powerful sexual being, but she is also a harmonious blend of the finest qualities that East and West can offer. In noticing that "there was something subtly oriental about those eyes while at the same time they projected a Western, almost subliminal sense of innocence and wordliness warring within" (Simmons:32; emphasis added), Luczack, the over-intellectualised male Westerner, performs a regional, adhoc fashioning of the 'perfect female', physically speaking, which, ironically, also signifies the lowering of his status from flâneur to badaud. This taking over of the male spirit and body by the devilish but all-seductive female is later achieved in an instant of what Hollander calls "notional ekphrasis", i.e. mental processes such as dreams, thoughts and whimsies of 
the imagination (Hollander:210). In the book's most powerfully erotic episode, Luczack dreams of making love to Kali herself, a goddess of perfect beauty, this time the personification of every man's desire, holding and offering from her many hands the secrets of carnal bliss. The third, 'personal' encounter with Kali (distinct from the mediated one via Luczack's listening to others' stories of human sacrifices, cemeteries and a general imagery suggestive of Calcutta as the land of unspeakable horrors) is marked by a sudden and irreparable rupture in the fabric of the quasirealistic substance the text has displayed so far. Moreover, this final encounter is pure and harsh male-female confrontation, in a land which has the potential to devour the male and confirm the female in her extreme, supernatural and maleficent powers. Having barely escaped from the hands of the outlaws who want him dead because he has provided Das with a weapon with which to end his destiny as an acolyte of the goddess, Luczack is left to face an idol-turned-murderous-flesh, a Kali alive with the desire to annihilate him:

Kali opened her mouth and hissed at me. Her jaw gaped wide. The crimson tongue slid out, five inches, ten inches: it unrolled like crimson, melting wax, until it touched the floor where it curled at the tip like a questing serpent and slid quickly across the cold stone toward me. (Simmons:167)

The lethal effects of the confrontations between the Western male intellectual and Kali, the Eastern deity, are all too obvious. After encountering Khamakya/Kali, Luczack stops experiencing, exploring, and interrogating the city. Instead, he gawks, gapes and allows himself to be dragged helplessly into the hallucinating world of the terrifying urban. Calcutta/as Khamakya/as Kali takes over and demands capitulation and 
supreme sacrifice from those who transgress her territory and attempt to reveal her secrets. Khamakya is a con-artist who is no relation to Das, the object of Luczack's investigations. Instead, she is exposed at the end of the book as a member of "the thuggees, goondas, or the so-called Kapalikas", "various criminal elements" who "often call upon a corrupt, Tantric form of mysticism, frequently invoking local deities - in this case, Kali - in order to impress their initiates or to frighten the common people" (Simmons:187). The significance of her name itself is also revealed at the end of the novel, as "Kamakhya, or its variant, Kamaksi", which "is associated with a particularly unattractive aspect of Kali once worshipped in the great temple at Assam" with ceremonies" so "very unwholesome" that "the cult was outlawed" and "their temple is abandoned" (Simmons:188). She is also the person who kidnaps Victoria, Robert and Amrita's infant daughter, and hands her over to others after having her body "used as a depository to transport stolen merchandise", such as rubies, sapphires, opals, amethysts, tourmaline (Simmons:201). Although Song of Kali ends in hideous death and loss, the couple return to America and, after a period of estrangement and separation, become parents once again. Furthermore, a castigated Luczack, the Western male initially keen to dominate the Eastern goddess and her realm, can finally start writing, "not poetry", "not for publication", but "a series of stories [...] about the adventures of a group of unlikely friends $[\ldots]$ a talking cat, a fearless and precocious mouse, a gallant but lonely centaur, and a vainglorious eagle who is afraid to fly", "a bedtime storybook" (Simmons:226).

As previously mentioned, Paul Theroux's novel is also centred on an encounter between Western male and Eastern setting in which the protagonist, as will be argued below, again unwittingly follows a 
typological trajectory from flâneur to badaud. In The Paris of the Second Time in Voltaire, Walter Benjamin contends that "No matter what trail the flâneur may follow, every one of them will lead him to a crime" (Benjamin:41). There are, according to McDonough, two possible readings of Benjamin's words; one of them considers the flâneur "a detective, tracking down the transgressions committed in the metropolis and imposing a species of social control over that lawless formation known as the crowd", while the other is suggestive of the "flâneur as himself criminal, his wanderings through the city streets as themselves perhaps criminal acts, inevitably leading him to a crime" (McDonough:101). I would like to add a third possible reading of the quotation from Benjamin, justified by the present context. Lured by the exoticism of Calcutta, the Eastern site of many a secret and of horrible wonders, Jerry Delfont, the flâneur/as detective is temporarily deprived of his investigative qualities and transgresses the safe boundaries of cool intellect to sample the sensuality of setting and character. Thus, he metamorphoses into the badaud, the gaper, the gawker, the most improbable type, that of the passive male. Consequently, the discovery of the crime is postponed almost indefinitely, since the female perpetrator becomes the potent manipulator and investigator of a disempowered male psyche. This, in short, is the relationship between Jerry Delfont and the femme fatale of the novel, Mrs Unger. Mrs Unger initially enters the story as an avatar of Mother Teresa (whom she later on confesses that she despises), an enigmatic humanitarian and child-saver, the manager of a large orphanage. She is also an extremely practical business woman, a racial Other (a black woman passing for white), and, as Delfont learns from Paul Theroux himself, "a dakini, a kind of priestess" "who taught tantric massage to a French actress who'd come out to work with Mother T" (Theroux:126). 
Although already infatuated with the seductive American philanthropist, Delfont's turning into a badaud occurs when he witnesses Mrs Unger at Kalighat temple in the role of the Kali-devotee who meticulously relishes the ritual of animal sacrifice:

Mrs Unger bent low to kiss the carcass of the black goat and when she straightened up she was smeared with blood, red streaks on her shawl. A shrill cry went up (Joi Kali!), joyous, cruelly triumphant, as she lifted her blood-smeared shawl from her head and draped it over the posts of the execution rack, along with a garland of blood-red lilies [...] The look on Mrs Unger's face was one of rapture, gleaming with sweat, the ringlets of her hair gummed to her cheeks, and she offered her face to the priest who, in one gesture of his dripping hand, marked her forehead with a fingertip of blood [...] We shuffled past an inside window where the image of the goddess Kali, gleaming black and brightly marked, stared with orange lozenge eyes from a stack of blossoms and offerings. I was briefly frightened, jostled by the mob in this stifling place of incense and flowers and dishes of money and frantic pilgrims, who were twitching with gestures of devotion and gasping, seeming to eat the air, all of them smiling wildly at the furious image (Theroux:102-103, emphasis added)

"Gasping, seeming to eat the air", and "smiling wildly" will be how Delfont will proceed to 'discover' the woman and Calcutta. In my reading, he represents the perfect embodiment of a Western badaud already consumed by urban, physical, psychological and physical realities that he is unable to comprehend. Most significant for the protagonist's journey from the hypostasis of detached and cool investigator towards that of urban dupe, Mrs Unger's skills as a Tantric masseuse gradually emasculate Delfont. His grasp of both her reality and the urban reality of Calcutta is delayed, in spite of intellectual encouragement from Howard, the American Embassy clerk: "It's pure Henry James. The big hidden clue hidden somewhere in the 
weave. Puzzle it out and you have the answer. You know the story? "The Figure in the Carpet"” (Theroux:204). The reading of the "Victorian texture" (Theroux:204) of the city of Calcutta through Henry James, with the implication of his authorial ability to lend the dubious fragrance of the past to the present, fails to make clear the incongruity of a character such as Mrs Unger in the wrongly-perceived Victorian reality of Calcutta. Undoubtedly, her multiple philanthropic actions designed to give dispossessed Indian children a chance of a better future would argue for the typical portrait of the selfless, all-giving Victorian woman of substance fond of helping the poor around her. Nevertheless, the fact that this saintly portrait is blurred by the veil of mystery carefully shrouding while exposing (to Delfont, at least) her oversexualised persona should suffice to disqualify her as any kind of 'Angel in the House'. This inconsistency is lost on the central character almost until the end, when he comes to piece together the missing parts of a puzzle of ruthless child exploitation and murderous determination whose artisan is the famous/infamous Mrs Unger. The writer as "[...] romantic voyeur" (Theroux:236), a phrase that Delfont uses in one of his pieces, plunges head first into the social reality of Mrs Unger's dark universe, where children can be employed as carpet weavers in factories owned by rich Americans, or 'adopted' by them for suspect purposes, and may occasionally end up dead in hotel rooms. It is as if a long-dead Dickensian London has somehow managed to extend its insalubrious life to present-day Calcutta, an urban space of horrors for the youngest of its dispossessed. Interestingly, it is the association with Kali that preserves the secret of Mrs Unger's so-called philanthropic acts. By “making puja at Kali Khoh temple" and prevailing "over adversity" "when the business was cracked down" (Theroux:243), Mrs Unger has acquired the status of 
"American Goddess" (Theroux:240) and refashioned herself as a Western counterpart of the Eastern deity, so as to better manipulate a mass of unsuspecting worshippers. However, her 'temple' is one where children live and work in "fear", "cowed and compact, like prisoners", in a factory which is no more than "a prison, a labour camp, filled with wooden flames and clattering; it was a mass of loose ends; it was a confusion of small souls toiling with tiny hands" (Theroux:249). Nightmare space imagery is translated into demonic persona characteristics. After witnessing the truth behind Mrs Unger's benevolent actions, Delfont, in my reading the gaper/badaud of the text, should be expected to regain his cynicism and once again dispassionately deploy the flâneur abilities with which he started his urban race. Nevertheless, when he confronts the woman/goddess, Delfont remarks on "Her two side teeth - eye-teeth, I suppose" which "bulged against her lips when she frowned and glistened, looking even more sinister when she smiled" (Theroux:252). Mesmerised by the angelic, equally mesmerised by the demonic, the writer's final judgements on Mrs Unger's persona cannot simply grasp her as a flawed human being, a mere $\operatorname{cog}$ in the machine of late capitalism. Thus, it is my contention that Theroux's narrative cannot dispel the overpowering shadow of Kali; known by her modus operandi, that of inexorably infiltrating the male mind with vivid fantasies and actings-out of unrestrained sexual experiments, debauchery and unorthodox carnal pleasures, coupled with violence and blood. As recurrent signifier, the Eastern goddess subjects the Western text and renders its protagonist strangely but convincingly ineffective. The very last lines of the novel witness to this deity-like grasp over the soul and the body of the writer, once a flâneur, then a badaud, but always a neophyte: 
I looked down at my hand, my fingers wrapped on the pen, poking at this last page, and I think of Mrs Unger, like an old flame, who gave me everything. But I didn't have to thank her for it, didn't have to be grateful. She was the illness and the cure, like a force of nature; life and death, the rain that gave hope, that flooded and drowned too; the pleasure and the pain (Theroux:265)

She was the Goddess in her realm.

\section{Conclusion:}

The present study has had at its core Kali, the much-vilified goddess from the Indian subcontinent, presiding over the Western collective cultural memory as a force of death, with gory superstitions and rituals, the very embodiment of the backwardness that the British colonial enterprise set out to eradicate. This imagery persists, in spite of the many 'reparatory' collections of texts and anthologies written by Westerners and Easterners alike. Such writings have focused on Kali's intricate cultural role, her manifold dimensions which confess to a more complex function than that rendered in classical Western representations, which have concentrated in a one-sided way on a process of denigration that was initiated in the nineteenth century and has endured down to the present day.

Nevertheless, the sensationalism of the negative representations of Kali in texts of both Western and Eastern origin by far outweighs positive or even more neutral assessments. The two novels that have constituted the focus of my comparative analysis testify to the persistence of this maleficent aura of Kali that cannot be easily dispelled, especially since, as I have argued, it can be held accountable for the metaphorical emasculation of the Western writer in Calcutta, Kali's realm par excellence. The conceptual frame employed, that of the writer as flâneur who turns badaud in the 
process of experiencing the horrible, the abject and the non-human in the Eastern metropolis, has also aimed at emphasising the devastating effects of a gendered confrontation with lethal consequences. Destructive encounter aside, my two selected texts may also advocate a different modality of assessing the urban experience, as suggested by their very endings. This is one that diverges from traditional perspectives which, at least in the rational West, constantly appear to favour the flâneur at the expense of the badaud. Perhaps, in lands of the unknown, one first has to gawk, stare and gape as a step towards really comprehending the local milieu. In Shaya's words, "the badaud", as he "belongs to a community of horror", "is nevertheless newly valorized since he is an emphatic observer, capable of reacting with fear and horror at greatly distressing sights" (Shaya:75). Thus, he almost displaces the figure of the flâneur, in spite of its ability to encapsulate "the experience of the modern city so well", with all its features of:

[...] urban alienation, the psychology of distraction provoked by the tumult of urban stimulation, the social and gender configurations of the city in the age of consumer capitalism. But the figure of the badaud offers us an insight on a parallel experience of modernity [...] where the flâneur experienced alienation and dislocation, the badaud partook in a community forged in the spectacle of suffering and outrage. (Shaya:76)

\section{References}

Baudelaire, Charles. 1986. "The Painter of Modern Life" in The Painter of Modern Life and Other Essays. Jonathan Mayne, ed. and trans. New York: Da Capo Press, pp. 1-40. Benjamin, Walter. 1997. Charles Baudelaire: A Lyric Poet in the Era of High Capitalism, Harry Zohn, trans. London and New York: Verso.

Hollander, John. 1988. “The Poetics of Ekphrasis.” Word \& Image 4:209-19.

Humes, Cynthia Ann. 2003. "Wrestling with Kali: South Asian and British Constructions of the Black Goddess" in Encountering Kali: In the Margins, at the Center, in the 
West. Rachel Fell McDermott and Jeffrey J. Kripal (Eds.). Berkeley: University of California Press, pp. 145-69.

Kinsley, David R. 2003. "Kali" in Encountering Kali: In the Margins, at the Center, in the West. Rachel Fell McDermott and Jeffrey J. Kripal (Eds.). Berkeley: University of California Press, pp. 23-39.

Kripal, Jeffrey. K, and Rachel McDermott. 2003. "Introducing Kali Studies" in Encountering Kali: In the Margins, at the Center, in the West. Rachel Fell McDermott and Jeffrey J. Kripal (Eds.). Berkeley: University of California Press, pp.1-19.

Magee, Michael. 1995. The Magic of Kali. http://www.shivashakti.com/MSS/magicofkali.pdf McDonough, Tom. 2002. "The Crimes of the Flaneur”. MIT Press. [Online]. pp. 101-122. Available: http://www.jstor.org/stable/779133 [Accessed 2015, June 18].

Menon, Usha and Richard A. Shweder. 2003. "Dominating Kali: Family Values and Tantric Power" in Encountering Kali: In the Margins, at the Center, in the West. Rachel Fell McDermott and Jeffrey J. Kripal (Eds.). Berkeley: University of California Press, pp. 80-100.

Shaya, Gregory. 2004. "The Flaneur, the Badaud, and the Making of a Mass Public in France, circa 1860-1910” in The American Historical Review [Online]. pp. 41-77. Available: http://www.jstor.org/stable/10.1086/530151[Accessed 2015, June 18]

Simmons, Dan. 1985. Song of Kali. New York: Tor Books.

Tagore, Rabindranath. Sacrifice.

http://tagoreweb.in/Render/ShowContent.aspx?ct=Plays\&bi=72EE92F5-BE50-

40C7-FE6E-0F7410664DA3\&ti=72EE92F5-BE50-4FE7-EE6E0F7410664DA3\&ch=c)

Taylor, Meadows. 1986. Confessions of a Thug. Oxford: Oxford University Press.

Theroux, Paul. 2010. A Dead Hand: A Crime in Calcutta. London: Penguin Books.

Van Woerkens, Martine. 2002. The Strangled Traveler: Colonial Imaginings and the Thugs of India. Chicago and London: The University of Chicago Press. 